\title{
Effects of the type and level of dietary fibre supplements on nitrogen retention and excretion patterns
}

\author{
BY INGE TETENS ${ }^{*}$, G. LIVESEY ${ }^{2}$ AND B. O. EGGUM ${ }^{1}$ \\ ${ }^{1}$ National Institute of Animal Science, Department of Animal Physiology and Biochemistry, \\ Research Centre Foulum, PO Box 39, DK-8830 Tjele, Denmark \\ ${ }^{2}$ Institute of Food Research, Norwich Laboratory, Norwich Research Park, Colney, \\ Norwich NR4 $7 U A$
}

(Received 3 January 1995 - Revised 28 April 1995 - Accepted 30 May 1995)

\begin{abstract}
The hypothesis was tested that fermentable dietary fibre (DF) sources elevate faecal $\mathrm{N}$ excretion at the expense of urinary $\mathbf{N}$ without affecting $\mathbf{N}$ retention. DF that substantially increase fermentation (pectin, sugarbeet and soya bran) or are poorly fermented (crystalline cellulose and maize bran) were fed as supplements to a basal DF-free diet at three dose levels : 0,50 and $100 \mathrm{~g}$ supplement $/ \mathrm{kg}$ basal diet. The diets were fed to juvenile male Wistar rats for 2 weeks before a $7 \mathrm{~d}$ period when faeces and urine were collected. Faecal excretion of $\mathbf{N}$ was significantly increased, dose-dependently, by all DF supplements and was positively correlated to faecal bulking. Urinary excretion of $N$ was lower at the high doses of the DF supplements but reached significance only with the highly fermentable (0.68) sugarbeetsupplemented diets. Regression analysis showed that the major part (0.75) of the increase in faecal $\mathrm{N}$ excretion due to DF supplementation was balanced by a reduction in urinary excretion; $\mathrm{N}$ retention was therefore, at the dose levels used, only affected to a small extent. Only in the maize-bran-supplemented diets were the reductions in $\mathbf{N}$ retention significant. The shift in $\mathrm{N}$ excretion from urine to faeces can be explained largely by the degree of microbial fermentation in the large intestine caused by the addition of DF supplements and emphasizes the modifying role that certain DF supplements may have on the enterohepatic cycle of $\mathrm{N}$. Possible implications of these findings for patients with liver or renal failure or for conditions when the intake of dietary protein is marginal are discussed.
\end{abstract}

Nitrogen retention: Nitrogen excretion: Dietary fibre

The evaluation of the quality of dietary protein has been of research interest almost since the beginning of nutritional science (Gallaher \& Schneeman, 1986). Protein quality is generally determined through measurements of $\mathrm{N}$ balance. In recent years particular interest has been shown in the influence on protein utilization of dietary components other than protein. The rapid expansion occurring in the number of high-dietary-fibre (DF) products or supplements available for consumers has increased the need for studies on the effects of these products on protein metabolism, including effects on digestibility and utilization.

Earlier studies with rats (Mason \& Palmer, 1973) demonstrated different effects on faecal $\mathrm{N}$ excretion after intake of various starches. Studies in pigs with infusion of maize starch in to the terminal ileum (Misir \& Sauer, 1981) or infusion of maize and potato starches into the caecum (Just et al. 1981) showed that easily fermentable substrates reduce apparent $\mathrm{N}$ digestibility. Effects of easily fermentable carbohydrates may be different from those of less fermentable DF.

* Present address: Research Department of Human Nutrition, Royal Veterinary and Agricultural University, Rolighedsvej 25, DK-1958 Frederiksberg C., Denmark. 
That DF has physiological actions along the gastrointestinal (GI) tract has also been well established (Eastwood \& Morris, 1992). In the small intestine DF may modify, and usually decreases, the digestibility of $N$ (Kritchevsky, 1988) while in the large intestine DF may alter considerably the metabolism of the bacteria residing in this part of the GI tract, which may lead to a profound change in $\mathrm{N}$ excretion patterns and possibly affect the overall $\mathrm{N}$ balance (British Nutrition Foundation, 1990). Generally it is found that DF has a bulking effect.

In a recent comparative study it was concluded that some differences might exist between man and the rat in the ability to digest $\mathrm{N}$ and to ferment dietary fibre but that the ranking of nutrient digestibility was the same in the two species (Bach Knudsen et al. 1994). Given the difficulties with methods for analysis of DF and the wide variations in digestibility of DF observed between laboratories, the similarity in DF digestibility between man and rat is remarkable (Livesey, 1992).

In the present study we have measured the effects on $\mathrm{N}$ excretion patterns and $\mathrm{N}$ retention in rats of feeding DF sources of varying solubility and fermentability. The effect of dose levels of DF supplements on excretion and retention of $\mathrm{N}$ was determined. Additionally, the correlation between faecal excretion of $\mathrm{N}$ and of DM was examined.

\section{METHODS}

The observations were made on animals from one laboratory in a study originally designed as a European Union interlaboratory study to determine energy conversion factors for DF supplements and fermentabilities of NSP contained in the supplements investigated, the results of which are published elsewhere (Livesey et al. 1995).

\section{Diets}

The design involved dietary treatments in which five DF supplements were each added at three doses $(0,50$ or $100 \mathrm{~g} / \mathrm{kg}$; Table 1$)$.

The five DF supplements were selected to have negligible or minimal starch content and to have a wide range of fermentability. The DF comprised: apple pectin, a high-methoxyl pectin from Sanofi Bio-Industries (Paris, France); maize bran from Honeyville Grain Inc. (Salt Lake City, Utah 84120, USA); cellulose ('Solca Floc'), grade BW 2030, from Jurgenson and Wettre Ltd, Wokingham, Berks.); sugarbeet DF ('Betafibre') from British Sugar plc (Peterborough, Cambs.) and soya bran ('Fibrim 2000 (red)') from Protein Technologies International (Corby, Northants).

\section{Animals}

Male Wistar rats ( $n$ 120), with a mean body weight of 88.4 (SD 5.9) g, were obtained from a local supplier (Molgaards Breeding Centre, Lille Skensved, Denmark). Throughout the study each rat was kept individually in a plexiglass metabolism cage with a stainless-steel mesh bottom and in a controlled environment (temperatures of $22-24^{\circ}$, relative humidity $50 \%$, light-dark period cycles of $12 \mathrm{~h}$ : 06.00-18.00 hours).

\section{Experimental design}

The study comprised five consecutive $\mathrm{N}$ balance studies. On each occasion twenty-four rats were allocated randomly to one of the dietary treatments, two rats per DF source at each dose level and four rats per basal diet. In total this made 120 observations ( 5 occasions $\times(5$ DF sources $\times 2$ doses $\times 2$ rats +4 basal-diet-fed rats)). The rats were fed for a total of $21 \mathrm{~d}$, divided into an adaptation period of $14 \mathrm{~d}$ and a balance period of $7 \mathrm{~d}$. 
Table 1. Composition of basal and experimental diets

\begin{tabular}{|c|c|}
\hline \multicolumn{2}{|l|}{ Composition of basal diet } \\
\hline Maize starch $(100 \mathrm{~g} \text { moisture } / \mathrm{kg})^{*}$ & $330 \mathrm{~g}$ \\
\hline Sucrose $(10 \mathrm{~g}$ moisture $/ \mathrm{kg})$ & $360 \mathrm{~g}$ \\
\hline Casein $(50 \mathrm{~g}$ moisture $/ \mathrm{kg}) \dagger$ & $200 \mathrm{~g}$ \\
\hline DL-Methionine & $2 \mathrm{~g}$ \\
\hline Maize oil\$ & $80 \mathrm{~g}$ \\
\hline Vitamin mixture§ & $20 \mathrm{~g}$ \\
\hline Mineral mixture & $40 \mathrm{~g}$ \\
\hline Total weight & $1032 \mathrm{~g}$ \\
\hline \multicolumn{2}{|l|}{ Composition of experimental diets } \\
\hline & Basal diet $\uparrow$ Fibre supplement \\
\hline Basal diet & $1000 \mathrm{~g}+0 \mathrm{~g}$ \\
\hline Lower dose dietary fibre supplement & $1000 \mathrm{~g}+50 \mathrm{~g}$ \\
\hline Higher dose dietary fibre supplement & $1000 g+100 g$ \\
\hline
\end{tabular}

* 'Snowflake' maize starch from Corn Products Ltd, Manchester.

$\uparrow$ Edible casein, mesh 30, from G. Fiske and Co. Ltd, Richmond, Surrey.

\$ Mazola from CPC International, Esher, Surrey.

$\S$ Produced the following amounts in the basal diet $(\mathrm{mg} / \mathrm{kg})$ : nicotinic acid 60 , cyanocobalamin in mannitol 50 , calcium D-pantothenate 40 , thiamin hydrochloride 10 , riboflavin 10 , pteroylmonoglutamic acid 10 , pyridoxine 10 , D-biotin 1, phylloquinone 2, Rovimix E-50 (containing $7.5 \mathrm{mg}$ RRR-tocopherol acetate, Roche, Welwyn Garden City, Herts.), Rovimix A-500 (containing $3.75 \mathrm{mg}$ retinol, Roche) 25 , Rovimix $\mathrm{D}_{3}-500$ (containing $0.19 \mathrm{mg}$ cholecalciferol, Roche) 15, choline bitartrate 1800, maize starch carrier ('Snowflake') 17800.

1 Produced the following amounts in the basal diet $(\mathrm{g} / \mathrm{kg}): \mathrm{CaHPO}_{4} 13, \mathrm{CaCO}_{3} 8 \cdot 2, \mathrm{KCl} 7 \cdot 04, \mathrm{Na}_{2} \mathrm{HPO}_{4} 7 \cdot 4$, $\mathrm{MnSO}_{4} 0 \cdot 18, \mathrm{MgSO}_{4} \cdot \mathrm{H}_{2} \mathrm{O} 0 \cdot 18, \mathrm{FeSO}_{4} 0 \cdot 144, \mathrm{CuSO}_{4} 0 \cdot 023, \mathrm{KIO}_{3} 0 \cdot 001$.

II Nitrogen content $(\mathrm{g} \mathrm{N} / \mathrm{kg} \mathrm{DM}$ ) : basal diet 30.7 ; pectin 6.6 ; maize bran 9.4 ; cellulose 0.8 ; sugarbeet 15.5 ; soya bran 17.9; For further details of supplements, see p. 462.

Each day the rats received, between 09.00 and 10.00 hours, $15 \mathrm{~g}$ basal diet or $15 \cdot 8 \mathrm{~g}$ lower dose DF-supplemented diet or 16.5 g higher dose DF-supplemented diet. Any spillage from the previous day was added to the daily ration. Water was available $a d l i b$. The body weight of each animal was recorded in a prefed state on days 1, 15 and 22 of the study.

During the $7 \mathrm{~d}$ balance period faeces were collected daily before feeding. The faecal collections from each animal were pooled and kept in the freezer at $-18^{\circ}$ until dry weight and $\mathrm{N}$ measurements were made. Urine was collected quantitatively in a glass vessel throughout the $7 \mathrm{~d}$ balance period. The urine samples were preserved with dilute $\mathrm{H}_{2} \mathrm{SO}_{4}$ $(0.5 \mathrm{M})$ until $\mathrm{N}$ determination.

\section{Chemical analyses}

DM in DF supplements, diets and faeces was determined on duplicate samples by ovendrying at $105^{\circ}$ for $20 \mathrm{~h}$. N was determined on duplicate samples of DF supplements, diets, freeze-dried faeces and wet urine by an automatic Kjeldahl procedure (KjellFoss 16200; Foss Electric A/S, Denmark).

\section{Calculations and statistical analyses}

$\mathrm{N}$ retention was calculated using equation 1 :

$$
\mathrm{N}_{\text {retention }}=\mathrm{N}_{\text {intake }}-\left(\mathrm{N}_{\text {urine }}+\mathrm{N}_{\text {faeces }}\right) \text {. }
$$

$\mathrm{N}$ digestibility was calculated as apparent digestibility using equation 2 :

$$
\text { Apparent } \mathrm{N}_{\text {digestibility }}=\left(\mathrm{N}_{\text {intake }}-\mathrm{N}_{\text {faeces }}\right) / \mathrm{N}_{\text {intake }} \text {. }
$$


Table 2. Nitrogen intake, retention and excretion in rats fed on a basal diet or diets supplemented with dietary fibre at low or high dose levels

(Values are means for ten rats (supplemented diets) or twenty rats (basal diet))

\begin{tabular}{|c|c|c|c|c|c|}
\hline & $\begin{array}{c}\text { Dose } \\
(\mathrm{g} / \mathrm{kg})\end{array}$ & $\begin{array}{c}\text { N intake } \\
(\mathrm{mg} / \mathrm{d})\end{array}$ & $\begin{array}{c}\mathrm{N} \text { retention } \\
\text { (N retention/ } \\
\mathrm{N} \text { intake) }\end{array}$ & $\begin{array}{c}\mathrm{N} \text { urine } \\
\text { (N urine/ } \\
\mathrm{N} \text { intake) }\end{array}$ & $\begin{array}{c}\mathrm{N} \text { faeces } \\
\text { ( } \mathrm{N} \text { faeces/ } \\
\mathrm{N} \text { intake) }\end{array}$ \\
\hline Basal diet & - & $433 \cdot 0^{\mathrm{fg}}$ & $0 \cdot 502^{\mathrm{a}}$ & $0 \cdot 450^{\mathrm{abc}}$ & $0.050^{\mathrm{E}}$ \\
\hline Pectin & 50 & $437.9^{\text {dee }}$ & $0 \cdot 472^{\mathrm{ab}}$ & $0-452^{\text {abc }}$ & $0.076^{6 \mathrm{~d}}$ \\
\hline Pectin & 100 & $432 \cdot 7^{78}$ & $0 \cdot 471^{\text {ab }}$ & $0.439^{\text {abc }}$ & $0-092^{\mathrm{ab}}$ \\
\hline Maize bran & 50 & $438 \cdot 8^{\text {der }}$ & $0 \cdot 453^{\mathrm{b}}$ & $0.480^{a}$ & $0.065^{\mathrm{e}}$ \\
\hline Maize bran & 100 & $440 \cdot 4^{\text {de }}$ & $0.452^{\mathrm{b}}$ & $0.464^{\text {abe }}$ & $0.085^{b c}$ \\
\hline Cellulose & 50 & $430 \cdot 4^{\mathrm{g}}$ & $0-481^{a b}$ & $0.458^{\text {abe }}$ & $0.061^{\mathrm{eP}}$ \\
\hline Cellulose & 100 & $441 \cdot 1^{\text {vd }}$ & $0.479^{\mathrm{ab}}$ & $0.450^{\text {abc }}$ & $0.071^{\text {de }}$ \\
\hline Sugarbeet & 50 & $442 \cdot 0^{\text {cd }}$ & $0.450^{\mathrm{b}}$ & $0.470^{\mathrm{ab}}$ & $0.082^{\text {he }}$ \\
\hline Sugarbeet & 100 & $450 \cdot 4^{b}$ & $0.477^{\mathrm{ab}}$ & $0.423^{\circ}$ & $0 \cdot 100^{\mathrm{a}}$ \\
\hline Soya bran & 50 & $447.7^{\mathrm{bc}}$ & $0.477^{\mathrm{ab}}$ & $0.442^{\mathrm{abc}}$ & $0.080^{\text {cd }}$ \\
\hline Soya bran & 100 & $457.5^{a}$ & $0-470^{\mathrm{ab}}$ & $0.431^{\mathrm{bc}}$ & $0.096^{\mathrm{a}}$ \\
\hline Mean $(n$ 120) & & 440.4 & 0.474 & 0.451 & 0.076 \\
\hline $\mathrm{SE}^{*}$ & & $7 \cdot 7$ & 0.050 & 0.049 & 0.012 \\
\hline \multicolumn{6}{|c|}{ Statistical significance of } \\
\hline Diet, $P<$ & & & $0 \cdot 055$ & NS & $0 \cdot 0001$ \\
\hline Dose, $P<$ & & & NS & NS & $0 \cdot 0001$ \\
\hline Diet $\times$ dose, $P<$ & & & NS & NS & NS \\
\hline
\end{tabular}

a-g Mean values within a column with unlike superscript letters were significantly different $(P<0-05)$ according to Student's least significant difference test (df 108).

* Standard error of the analysis between diets, within dose of dietary fibre supplement.

The results were initially examined in two-way ANOVA (Armitage, 1971):

$$
X_{\mathrm{ijk}}=\mu+\alpha_{\mathrm{i}}+\beta_{\mathrm{j}}+(\alpha \beta)_{\mathrm{ij}}+\epsilon_{\mathrm{ijk}},
$$

where $X_{\mathrm{ijk}}$ is the dependent variable, $\mu$ is the overall mean, $\alpha_{\mathrm{i}}$ is the effect of diet, $\beta_{\mathrm{j}}$ is the effect of dose of DF supplement and $\epsilon_{1 j \mathrm{k}}$ is the normally distributed random variable. When a factor was not significant either as a main effect or in interactions it was omitted from the statistical model and so included in the error (root mean square error (MSE)) of the statistical test. Standard errors (SE) presented in the tables are derived from the root MSE. All differences between means were tested at $P<0.05$, using a $t$ test (least significant difference; LSD). Correlation and regression analyses were performed on individual figures. The Statistical Analysis Systems (SAS) statistical software package was used (SAS Release 6.04, SAS Institute Inc., Cary, NC, USA).

\section{RESULTS}

\section{Animal performance}

All diets (Table 1) were well received by all the animals with very little daily feed refusal. Due to the supplementary feeding of the DF, DM intake was higher in the DFsupplemented groups than in the group receiving the basal diet alone. The total DM intake over the $7 \mathrm{~d}$ balance period in the rats receiving the basal diet $(n 20)$ was $98.5(\mathrm{SD} 0.91) \mathrm{g}$, in the rats $(n 50)$ receiving the lower dose DF-supplemented diets it was 103.6 (SD 0.80) $\mathrm{g}$, and in the rats $(n 50)$ receiving the higher dose DF-supplemented diets it was $108 \cdot 4$ (SD 1.01) g. 


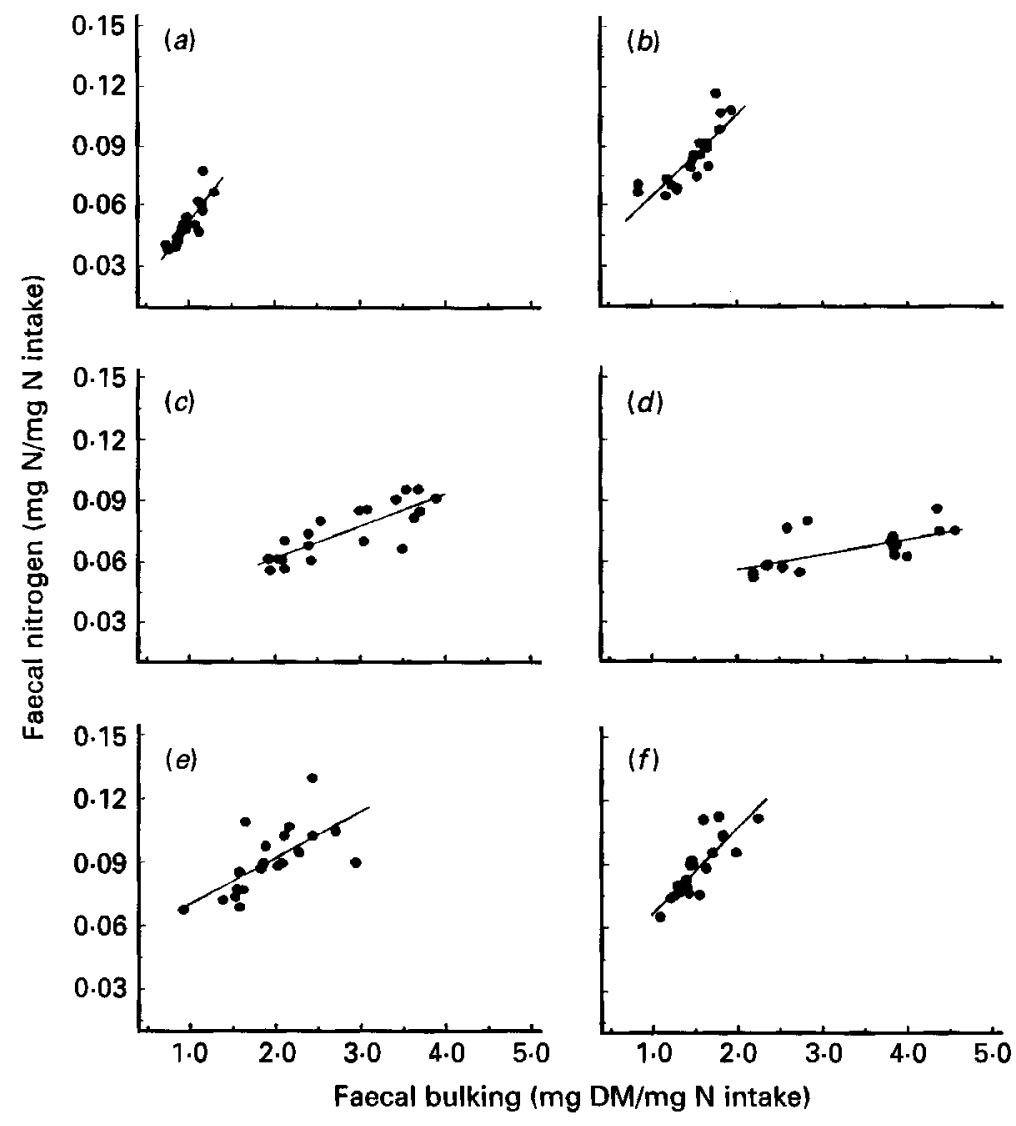

Fig. 1. Regression of faecal bulking (mg DM/mg $\mathrm{N}$ intake) $v$. faecal nitrogen (mg faecal $\mathrm{N} / \mathrm{mg} \mathrm{N}$ intake) in rats fed on a basal diet or on the same basal diet supplemented with a dietary fibre source. (a), Basal diet: $r 0 \cdot 87, P$ $<0.0001$, SE 0.006; (b), pectin-supplemented diets: $r 0.83, P<0.0001$, SE 0.010; (c), maize-bran-supplemented diets: $r 0.83, P<0.0001$, SE 0.008; (d), cellulose-supplemented diets: $r 0.66, P<0.005$, SE 0.009; (e), sugarbeetsupplemented diets: $r 0.67, P<0.005$, SE 0.013; (f), soya-bran-supplemented diets: $r 0.82, P<0.0001$, SE 0.007 (df 19 in each dietary group).

Mean body weight of all 120 rats after the $14 \mathrm{~d}$ adaptation period was 181.0 (SD $7 \cdot 3) \mathrm{g}$. Body-weight gain during the $7 \mathrm{~d}$ balance period was similar in all dietary groups with an average of 33.8 (SD 4.9$) \mathrm{g}$.

\section{Nitrogen intake and retention}

The $\mathbf{N}$ content of the experimental diets reflected the $\mathbf{N}$ dilution that occurred when the basal diet was supplemented with DF supplements containing negligible (pectin, maize bran and cellulose DF supplements) or very low levels (sugarbeet and soya bran DF supplements) of $\mathrm{N}$ (footnote, Table 1). Due to the $\mathrm{N}$ content of the sugarbeet and soya bran DF supplements the average daily $\mathbf{N}$ intake in these dietary groups differed between doses and from the basal diet. All these differences in $\mathrm{N}$ intake were small in both absolute and relative terms.

$\mathrm{N}$ retention was influenced by diet $(P<0.055)$ but not by dose of DF supplements (Table 2). The DF supplements tended to reduce $\mathrm{N}$ retention in all diets but the reductions 


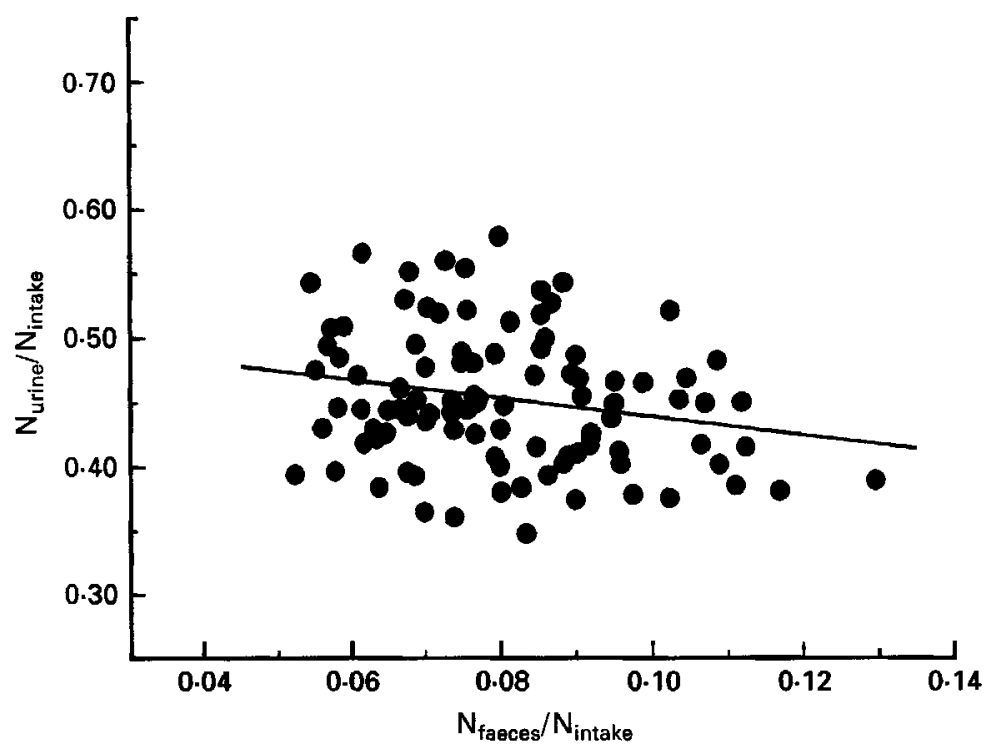

Fig. 2. Regression of nitrogen excretion in faeces $v$. that in urine in rats fed on a basal diet supplemented with various dietary fibre souces. The regression line is described by the equation $Y=0.51-0.72 X ; n 100, \mathrm{df} 98(r 0.23$, $P<0.02$, sE 0.013).

reached significance only in the two groups, those given maize bran and those given the lower dose sugarbeet DF.

\section{Nitrogen excretion}

Faecal $\mathrm{N}$ excretion was significantly $(P<0.0001)$ influenced by both the diet and the dose of DF supplement (Table 2). Compared with the basal diet all DF supplements caused a significant increase in faecal $\mathrm{N}$. No interaction was found between diet and dose.

In all the DF-supplemented diets a reduction in the urinary $\mathbf{N}$ excretion was seen at the higher dose compared with the lower dose. Only in the case of the sugarbeet-supplemented diets did the difference reach significance.

\section{Relation between faecal nitrogen excretion and faecal bulking}

Faecal bulking calculated as average DM excretion/ $\mathrm{N}$ intake per rat per day ranged from an average of 0.981 (SD 0.14) $\mathrm{mg} \mathrm{DM} / \mathrm{g} \mathrm{N}$ intake in the basal dietary group to 4.03 (SD 0.27) $\mathrm{mg} \mathrm{DM} / \mathrm{g} \mathrm{N}$ intake in the high-dose cellulose-supplemented group. Faecal $\mathrm{N}$ excretion was positively correlated to faecal bulking. With the data divided into the different diets the Pearson correlation coefficients ranged from 0.66 in the cellulosesupplemented diets to 0.87 in the basal diet (Fig. 1).

\section{Relation between faecal and urinary nitrogen excretion}

The large loss of $\mathrm{N}$ to urine compared with that to faeces, together with relatively few observations per diet, made it difficult to observe for each DF supplement whether a decrease in urinary $\mathbf{N}$ excretion occurred to compensate for the increase in faecal $N$. Among all those animals given DF, i.e. excluding those given no fibre, the urinary $\mathrm{N}$ excretion decreased with increasing faecal $\mathrm{N}$ excretion (Fig. 2). The exchange was 0.72 (SE 0.013$) \mathrm{g}$ urinary $\mathrm{N}$ for $1 \mathrm{~g}$ faecal $\mathrm{N}(P<0.02)$, suggesting that almost 0.75 of the faecal $\mathrm{N}$ was compensated by a reduction in urinary $\mathrm{N}$. 


\section{DISCUSSION}

The DF supplements chosen for the present experiment were purified fibre sources that are commercially available for human consumption. The supplements were selected for their negligible or low levels of starch and their expected wide range of fermentabilities. The fermentability of the DF sources was determined previously in a pan-European study reported by Livesey et al. (1995) where the average fermentabilities of the DF supplements were, in descending order : pectin $0 \cdot 93$, soya bran $0 \cdot 87$, sugarbeet $0 \cdot 68$, maize bran $0 \cdot 16$, and cellulose $0 \cdot 07$. The choice of purified fibre supplements rather than fibre-rich foods had the advantage of negligible or low levels of $\mathrm{N}$ or other energy-contributing substances that could otherwise interfere with the variables examined.

The method of incorporation of the DF source is of particular interest when studying effects on $\mathrm{N}$ utilization. The two methods usually employed in these types of study are substitution and supplementation of a basal diet with the DF sources (Gallaher \& Schneeman, 1986). The advantage of the supplementation method is that the $\mathrm{N}$ :energy ratio of the diets remains almost constant, a condition that is almost a prerequisite in studying protein utilization, especially in low-protein diets (Delorme et al. 1981). However, the energy value of DF is an issue of much recent debate (British Nutrition Foundation, 1990; Livesey, 1990). Using a rat model, the net metabolizable energy values of the DF supplements used in the present study were (kJ/g DF source): soya bran $8 \cdot 7$, pectin $7 \cdot 3$, sugarbeet $6 \cdot 7$, maize bran $2 \cdot 7$, cellulose $0 \cdot 2$ (Livesey et al. 1995). With the small contribution of the DF sources to total energy intake, the supplementation method applied in the present study seemed almost ideal.

The most established action of DF along the GI tract is the effect on stool weight (Cummings et al. 1992; Eastwood, 1992). Faecal DM consists mainly of bacterial matter with the remainder consisting of unfermented DF and other excreted compounds (Eastwood \& Morris, 1992). The pattern of DM excretion in the present study confirmed an inverse relationship between DM excretion and fermentability of the DF supplements.

The faecal $\mathrm{N}$ excreted is derived from incomplete digestion of bacterial protein (Mason, 1984), dietary protein, secreted digestive enzymes, and sloughed mucosal cells (Eggum, 1992). In the present study dietary protein was provided mainly by casein, a highly digestible $\mathrm{N}$ source, but small amounts of $\mathrm{N}$ were further supplied from the sugarbeet and soya bran DF supplements. $\mathrm{N}$ bound to the cell walls of these purified DF is less digestible than non-bound N (Donangelo \& Eggum, 1985) but due to the relatively high fermentation of these two DF sources ( 0.68 for sugarbeet and 0.87 for soya bran) the amounts of cellwall-bound $\mathrm{N}$ in faecal matter are considered to be of minor importance in the present study.

The addition of DF to a basal diet increases the flow of substrate to the large intestine, stimulates bacterial growth, and increases $\mathbf{N}$ incorporation into the bacterial cell walls (Goodlad \& Mathers, 1990). This has also been shown to be the case with certain types of starches whether taken orally (Mason \& Palmer, 1973) or infused into the caecum (Just et al. 1981). Based on these observations it is possible, therefore, to predict that any fermentable polysaccharide has similar effects on $\mathrm{N}$ excretion patterns.

In the present study an association was observed between the degree of fermentation of the DF supplements and the faecal concentration of $\mathrm{N}$. The poorly fermentable DF supplements (cellulose and maize bran) increased faecal bulking and thus led to a dilution of faecal N. In contrast, the highly fermentable DF supplements (pectin, sugarbeet and soya bran) led to an increase in bacterial growth and a reduction in the amount of DF residue resulting in a $\mathrm{N}$ enrichment of faecal matter (Fig. 1).

The microbial degradation of complex carbohydrates that occurs in the large intestine 
during bacterial fermentation leads to considerable changes in the colonic $\mathrm{N}$ metabolism. The total bacterial $\mathrm{N}$ requirement which is elevated by the stimulation of bacterial protein synthesis is mainly derived from $\mathrm{NH}_{3}$ in the large intestine (Wrong \& Vince, 1984). The main source of this intestinal $\mathrm{NH}_{3}$ is endogenous urea (Rémésy \& Demigné, 1989).

When data from all DF treatments were considered the reduction in urinary $\mathrm{N}$ excretion compensated the major part of the elevated faecal $\mathrm{N}$ excretion (Fig. 2). A reduction in protein digestibility may not be a major concern in diets where protein is not a limiting dietary factor for growth and maintenance as was the case in the present study. However, under conditions where dietary protein intake is marginal a reduction in protein digestibility due to high intakes of DF supplements may make a difference between protein adequacy and inadequacy. A reduction of urinary $\mathbf{N}$ excretion due to high intakes of DF supplements may be warranted in certain clinical situations, i.e. patients with liver or renal failure.

The elevated excretion of faecal $\mathrm{N}$ after eating more $\mathrm{DF}$ has long been used to argue that DF will both decrease $\mathrm{N}$ retention in the body and impair growth rates. This research shows that this is not the case, rather that urinary $\mathrm{N}$ excretion decreases to compensate for most of the increase in faecal $\mathrm{N}$ loss. The enterohepatic recycling of $\mathrm{N}$ is the probable mechanism, leading to decreased urea excretion, increased microbial urealysis and increased microbial de novo amino acid and protein synthesis.

\section{CONCLUSION}

The present study confirms our hypothesis that DF added to a basal diet significantly affects $\mathrm{N}$ excretion in growing rats, increasing faecal $\mathrm{N}$ losses and decreasing urinary $\mathrm{N}$, due to greater fermentation in the hind gut. A major part of the increase in faecal $\mathrm{N}$ is compensated by the decrease in urinary $\mathrm{N}$.

We are grateful that the Dietary Fibre Task Force of the International Life Sciences Institute - ILSI, Europe, allowed us to use one of their feeding trials to make measurements of $\mathrm{N}$ intake and excretion. The authors wish to express their appreciation for skilful technical assistance to Ms Connie Jakobsen and Ms Kathrine Hoirup. Dr Torben Larsen, National Institute of Animal Science, Tjele, Denmark contributed with fruitful discussions on the statistics.

\section{REFERENCES}

Armitage, P. (1971). Statistical Methods in Medical Research. Oxford: Blackwell Scientific Publications.

Bach Knudsen, K. E., Wisker, E., Daniel, M., Feldheim, W. \& Eggum, B. O. (1994). Digestibility of energy, protein, fat and non-starch polysaccharides in mixed diets: comparative studies between man and the rat. British Journal of Nutrition 71, 471-487.

British Nutrition Foundation (1990). Complex Carbohydrates in Foods: The Report of the British Nutrition Foundation's Task Force. London: Chapman \& Hall.

Cummings, J. H., Bingham, S. A., Heaton, K. W. \& Eastwood, M. A. (1992). Fecal weight, colon cancer risk and dietary intake of nonstarch polysaccharides (dietary fiber). Gastroenterology 103, 1783-1789.

Delorme, C. B., Wojcik, J. \& Gordon, C. (1981). Method of addition of cellulose to experimental diets and its effect on rat growth and protein utilization. Journal of Nutrition 111, 1522-1527.

Donangelo, C. M. \& Eggum, B. O. (1985). Comparative effects of wheat bran and barley husk on nutrient utilization in rats. 1. Protein and energy. British Journal of Nutrition 54, 741-751.

Eastwood, M. A. (1992). The physiological effect of dietary fiber: an update. Annual Review of Nutrition 12, 19-35.

Eastwood, M. A. \& Morris, E. R. (1992). Physical properties of dietary fiber that influence physiological function: a model for polymers along the gastrointestinal tract. American Journal of Clinical Nutrition 55, 436 442.

Eggum, B. O. (1992). The influence of dietary fibre on protein digestion and utilisation. In Dietary Fibre - A Component of Food. Nutritional Function in Health and Disease, pp. 153-165 [T. F. Schweizer and C. A. Edwards, editors]. London: Springer-Verlag.

Gallaher, D. \& Schneeman, B. (1986). Effect of dietary fiber on protein digestibility and utilization. In $C R C$ Handbook of Dietary Fiber in Human Nutrition, pp. 143-164 [G. A. Spiller, editor]. Florida: CRC Press. 
Goodlad, J. S. \& Mathers, J. C. (1990). Large bowel fermentation in rats given diets containing raw peas (Pisum sativum). British Journal of Nutrition 64, 569-587.

Just, A., Jørgensen, H. \& Fernandez, J. A. (1981). The digestive capacity of the caecum-colon and the value of the nitrogen absorbed from the hind gut for protein synthesis in pigs. British Journal of Nutrition 46, 209-219.

Kritchevsky, D. (1988). Dietary fiber. Annual Review of Nutrition 8, 301-328.

Livesey, G. (1990). Energy values of unavailable carbohydrate and diets: an inquiry and analysis. American Journal of Clinical Nutrition 51, 617-637.

Livesey, G. (1992). The energy values of diets and sugar alcohols for man. Nutrition Research Reviews 5, 61-84.

Livesey, G., Smith, T., Eggum, B. O., Tetens, I. H., Nyman, M., Robertfroid, M., Delzenne, N., Schweizer, T. F. \& Decombaz, J. (1995). Determination of digestible energy values and fermentabilities of dietary fibre supplements: a European inter-laboratory study in vivo. British Journal of Nutrition 74, 289-302.

Mason, V. C. (1984). Metabolism of nitrogenous compounds in the large gut. Proceedings of the Nutrition Society 43, 45-53.

Mason, V. C. \& Palmer, R. (1973). The influence of bacterial activity in the alimentary canal of rats on faecal nitrogen excretion. Acta Agricultura Scandinavica 23, 141-150.

Misir, R. \& Sauer, W. C. (1981). Nitrogen and amino acid metabolism in the hindgut of pigs fed barley or wheat diets as affected by the infusion of maize starch at the terminal ileum. Zeitschrift für Tierphysiologie, Tierernährung und Futtermittelkunde 46, 221-233.

Rémésy, C. \& Demigné, C. (1989). Specific effects of fermentable carbohydrates on blood urea flux and ammonia absorption in the rat cecum. Journal of Nutrition 119, 560-565.

Wrong, O. M. \& Vince, A. (1984). Urea and ammonia metabolism in the human large intestine. Proceedings of the Nutrition Society $43,77-86$. 